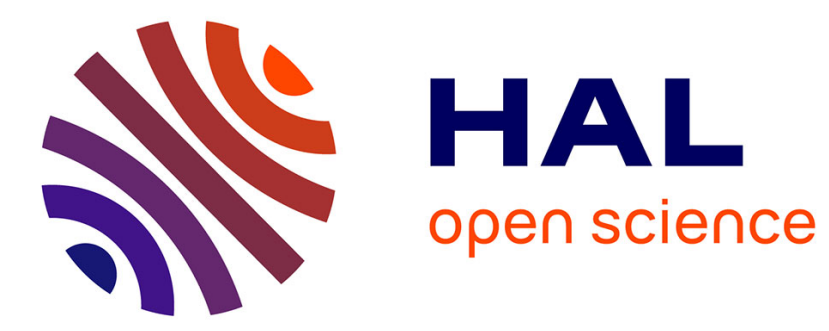

\title{
Soil and dust magnetism in semi-urban area Truskavets, Ukraine
}

\author{
O. Menshov, S. Spassov, Pierre Camps, S. Vyzhva, P. Pereira, T. \\ Pastushenko, V. Demidov
}

\section{- To cite this version:}

O. Menshov, S. Spassov, Pierre Camps, S. Vyzhva, P. Pereira, et al.. Soil and dust magnetism in semi-urban area Truskavets, Ukraine. Environmental Earth Sciences, 2020, 79 (8), 10.1007/s12665020-08924-5 . hal-02561866

\section{HAL Id: hal-02561866 \\ https://hal.umontpellier.fr/hal-02561866}

Submitted on 19 Oct 2020

HAL is a multi-disciplinary open access archive for the deposit and dissemination of scientific research documents, whether they are published or not. The documents may come from teaching and research institutions in France or abroad, or from public or private research centers.
L'archive ouverte pluridisciplinaire HAL, est destinée au dépôt et à la diffusion de documents scientifiques de niveau recherche, publiés ou non, émanant des établissements d'enseignement et de recherche français ou étrangers, des laboratoires publics ou privés. 


\section{Soil and dust magnetism in semi-urban area Truskavets, Ukraine}

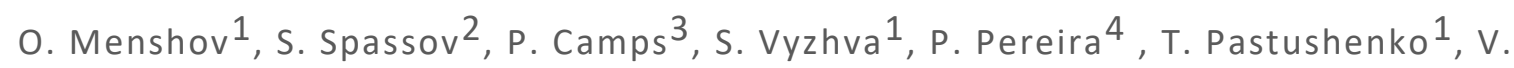
Demidov $^{1}$

\section{Abstract}

The objective of this paper was to study pollution in the semi-urban area of Truskavets (Ukraine) using lowcost and energy- efficient magnetic measurements. Soil magnetic properties were measured near a railway station (transect) and near a road (transect and grid). To compare the magnetic properties of the soils from the urban areas, we sampled in a forest area located 2-3 km from Truskavets. Additionally, ten dust samples were taken $150 \mathrm{~cm}$ above the ground from the smooth surface of the tree bark. Near the Stebnyk Ring (the end of the second transect), we established a grid $(20 \times 20 \mathrm{~m})$ and measured the soil magnetic susceptibility MS (mass-specific $X$, and volume $k$ ). There were taken 55 soil samples within the upper $0-5 \mathrm{~cm}$ of the topsoil. The results showed that low-frequency MS of the natural soil was within the range of $8-10 \times 10^{-8}$ $\mathrm{m}^{3} / \mathrm{kg}$, a low value for the Ukraine soils. The urban soils collected near the roadway and the railway had high MS values. Soil pollution was confirmed by the frequency dependence of magnetic susceptibility: $X_{f d}$ $=2-3 \%$. Our results, based on the thermomagnetic, hysteresis, isothermal (IRM), and anhysteretic remanent magnetization (ARM) measurements, suggested that magnetite is responsible for the increase in the magnetic signal of the urban soils. Natural soils normally contain a single domain (SD) grains. It has also been found that the high coercivity haematite and goethite are stable pedogenic minerals in the Truskavets natural soil. Overall, the magnetic measurements have proven to be a rapid, low cost, non-destructive and efficient technique for soil monitoring and air quality assessment.

Keywords : Soil magnetism · Environmental pollution · Magnetic susceptibility · Magnetic minerals

O. Menshov menshov.o@ukr.net

S. Spassov simo@meteo.be

P. Camps pierre.camps@umontpellier.fr

P.Pereira pereiraub@gmail.com

1 Taras Shevchenko National University of Kyiv, 90 Vasylkivska Str, Kyiv 03022, Ukraine

2 Institute Royal Meterologique de Belgique, Centre de Physique, 5670 Dourbes (Viroinval), Belgium

3 Géosciences Montpellier, CNRS and University of Montpellier, Case 060, 34095 Montpellier, Cedex 05, France 
4 Environmental Management Laboratory, Mykolas Romeris University, 08303 Vilnius, Lithuania

\section{Introduction}

With heavy metals having negative impacts on soil func- tions, the ecosystem services provided and human health (Dankoub et al. 2012; Taghipour et al. 2011), environmental pollution is one of the biggest threats and challenges for sus- tainability in urban areas (Brevik et al. 2018; Pereira etal. 2018). As pointed out by the World Health Organization in a recent report (May 2016) —-Ambient air pollution, made of high concentrations of small and fine particulate matter, is the greatest environmental risk to health causing more than 3 million premature deaths worldwide every year". These hazardous substances are mainly the result of anthropogenic activities (e.g. power plants, waste incineration and vehi- cle traffic) and their accumulation is especially detrimental in the vicinity of urban areas. Magnetic susceptibility MS (mass-specific $X$, and volume $\mathrm{k}$ ) measurements are increas- ingly used as an alternative to the traditional geochemical analyses (Liu et al. 2016) to determine concentrations of heavy metals and other pollutants that accumulate in soil and in the atmosphere as particulate matter (Cao et al. 2015; Magiera et al. 2015). Compared to other methods of moni- toring pollution levels, magnetic ones are rapid, low-cost and highly effective (Cho et al. 2015; Lu et al. 2016). Magnetic measurements can, therefore, yield extensive data derived from a large number of analyses and data points (i.e. up to several hundred in a few days depending on the magnetic parameter measured).

Previous studies into the MS of soils were searching for a rapid proxy technology of outlining areas exposed to increased pollution by atmospheric particulates of anthro- pogenic origin (Kapička et al. 1999; Bourliva et al. 2016; Liu et al. 2016; Norouzi et al. 2016). A number of studies have shown that magnetic monitoring is a robust technique for quantifying pollution particles produced by combustion and/or abrasion processes, toxic metals (Maher et al. 2008; Matzka and Maher 1999) and ambient PM10 concentrations (Mitchell et al. 2010).

There have been attempts to combine the study of MS and heavy metals in the soil. Liu et al. (2016) measured the MS and the concentrations of $\mathrm{As}, \mathrm{Cd}, \mathrm{Cr}, \mathrm{Cu}, \mathrm{Ni}, \mathrm{Pb}$ and $\mathrm{Zn}$ in the topsoil $(0-15 \mathrm{~cm})$ in China. The average pollution load index (PLI) of the metals in the urban soil was 2.53 , which was overall assessed as a moderate pollution level. A positive correlation was found between the PLI, the amounts of As, Cd, Cr, $\mathrm{Cu}, \mathrm{Ni}, \mathrm{Pb}$ and $\mathrm{Zn}$ in the soils and their MS. Yang et al. (2016) also analysed the values of MS and $\mathrm{Cu}, \mathrm{Zn}$, $\mathrm{Ni}, \mathrm{Pb}, \mathrm{Cr}$, Cd concentrations in 70 samples of con- taminated topsoil from the Linfen basin of China. Yurtseven- Sandker and Cioppa (2016) evaluated the long term effects of air pollutants emitted from an iron-sintering plant near Wawa (Ontario, Canada) decades ago (1939-1998) using MS. The MS enhancement at depths of 5-10 cm was found to be related to the presence of magnetic spherules (flyashes). Szuszkiewicz et al. (2016) examined four types of soils (Entic Podzol, Eutric Cambisol, Humic Cambisol and Dystric Cambisol) developed on various types of bedrock (Tumlin Sandstone, basaltoid, amphibolite and serpentinite) and found that MS values were significantly higher in the topsoil horizons due to the deposition of technogenic mag- netic particles. 
Over the past ten years, magnetic measurements have become an essential element of technology for environ- mental monitoring. Compared to the geological survey and agriculture, environmental pollution is a more developed sphere of soil magnetism application. Lourenço et al. (2014) demonstrated the efficiency of environmental magnetism techniques in tracing soil evolution and pollution history over time. Jordanova et al. (2014) used magnetic measure- ments to estimate $\mathrm{NO}_{2}$ levels. Cao et al. (2015) showed the practical and economic value of magnetic techniques applied in their study to assess the concentrations of atmospheric particulate matter (PM) in soils and leaves. The results obtained by Gargiulo and Chaparro (2016) highlight the importance of magnetic properties in monitoring the PM distribution in soils and other environmental PM collectors. Magnetic susceptibility was found to be a useful parameter in studying the impact of anthropogenic activities on river sediments (Frančišković-Bilinski et al. 2017). As very little information is available about the use of magnetic methods to compare natural soils and heavily polluted ones in indus- trialized areas, the region of Ukraine chosen provided a good study site. A major benefit of this study is using a low-cost method to identify the impacts of roads and railways on soils since these areas are known to be major sources of pollutants that can affect soil, water quality, ecosystem services and ultimately human health. The aim of the present study is to assess the impacts of anthropogenic activities on soil MS in Truskavets (Ukraine). The specific objectives include (a) measuring MS near a roadside and railway using transects and (b) using a grid to understand the spatial distribution of MS in an urban area.

\section{Materials and methods}

\section{Study area}

The semi-urban area of Truskavets, located in the western part of Ukraine, is part of the Drohobych-Borislav metro- politan area. The urban agglomeration includes the cities of Drogobych, Borislav, Stebnyk, and Skhodnitsa, which have close economic and cultural ties. Drohobych is the central city; Truskavets and Skhodnitsa are recreation cen- tres, whereas Stebnyk and Borislav are industrial centers. The local mining industry is based on the extraction of oil, potassium salt, and mineral wax (ozokerite). The modern manufacturing industry sectors operate on machinery and non-woven fabrics. Truskavets is a famous balneal resort. The first known record of the name of Truskavets dates back to 1427. In 2013, its population was estimated to be about 30,000 inhabitants. The greatest treasure of the resort is the sulphur-scented, slightly saline mineral water commonly known as the Naftusia brand. From the geological point of view, Truskavets lies in the inner zone of the Carpathian Foredeep, which comprises three distinct tectonic units, Bilche-Volytsya, Sambir, and Boryslav-Pokuttya. The geol- ogy of the region is represented by the saltbearing Voroty- shcha beds, referring to the Lower Molasse sediments of the Boryslav Pokuttya Unit in the internal part of the Carpathian Foredeep covering the Paleogene flysch succession, which is the main source of oil- and gas-bearing sediments of the Ukrainian Carpathians (Gadirov et al. 2018; Menshov et al. 2014; Slaczka et al. 2006). The relationship between soil magnetism and the hydrocarbon deposits in this area was studied in Menshov et al. (2016). In the urban part of the study area, the soils were classified as Technosols, while the meadow and forest soils were defined as Gleysols and Phaeozems (WRB 2015). The climate is temperate continen- tal, with an average annual temperature ranging from 6.5 to $8.8^{\circ} \mathrm{C}$. The average annual precipitation ranges from 629 to $1223 \mathrm{~mm}$. The landscape character of the study site, which 
is located near the Carpathian Mountains, is a non-urban for- ested area. Analyzing anthropogenic pressures in Truskavets, we identified two major sources of environmental pollution: road traffic and the railway network (Fig. 1).

Another anthropogenic factor is the industrial area of Stebnyk with its former power plants located not far from Truskavets. For over 600 years, Stebnyk was a large center of industrial salt, oil and ozokerite production. The long- term extraction resulted in the formation of huge voids, craters and quarry pits filled with potash sludge and other highly toxic compounds. These chemicals are likely to travel as airborne pollutants and/or make their way into the groundwater, which poses a threat to the drinking water, mineral springs and soils of Truskavets. With the network of abandoned mines and quarries being in close proximity to the urban soil of Truskavets, environmental monitoring is essential for the environmental safety of its semiurban area (Felipe-Sotelo et al. 2007).

\section{Sampling and measurements}

The magnetic properties of soils and dust were investigated along with two sampling sites (transects) and in a forest area for the identification of non-urban soil, serving as the control plot (see Fig. 1). Within the first transect (red line), samples were taken along the railway line starting from the Main Train Station of Truskavets, crossing in its central part the main roadway of the city, and ending in the forest, a total distance of $2 \mathrm{~km}$. Soils were measured in situ using a port- able MS meter and sampled for further laboratory analyses. Dust samples were taken from the smooth surface of tree bark with non-magnetic sponges, at a height of $150 \mathrm{~cm}$. The second transect (blue line) was laid along the circular road around Truskavets, which carries the highest traffic flows in the city. The measuring and sampling strategy was identical to that described above. At the end of the second sampling site near the Stebnyk Ring, we designed a grid (20 x $20 \mathrm{~m}$ ) to measure the magnetic susceptibility of the soil and per- formed soil sampling.

There were conducted both in situ and laboratory mag- netic studies of soils and dust. In our field study, we con- centrated on the soil science aspects of the landscapes and soils, as well as determining the types of soil in non-polluted areas. The most polluted areas were selected to study the road traffic and railway impact on soil and dust magnetism. One hundred surface topsoil samples (all from a depth of $0-2 \mathrm{~cm}$ ) were taken from the polluted sites along the tran- sects ( 60 samples along Transect 1 -red line, and 40 sam- ples along Transect 2-blue line in Fig. 1). Twenty soil sam- ples were taken randomly from the forest patch to identify the magnetic properties of the natural soil in the study area (yellow area in Fig. 1). Fifty-five samples were taken in the grid surveyed (a depth of $0-5 \mathrm{~cm}$ ). In addition, 10 samples of dust were taken from the tree bark. Sampling was accompa- nied by field MS measurements (volume magnetic suscepti- bility, $\mathrm{k}$ ). Field $\mathrm{k}$ measurements of soils were conducted with an PIMV-M portable MS meter (Geologorazvedka). The PIMV$\mathrm{M}$, which is roughly analogous to the conventional Czech KT-5, has a measuring range of $1 \times 10^{-5}-1 \mathrm{SI}$ units. The relative measurement error is: $\delta \leq 10 \%$ in the range $10^{-5}-10^{-4} \mathrm{SI}$. The device is based on the frequency method and is used for measuring magnetic susceptibility. Being a part of the low-frequency controller, the plane induction coil is the primary device located at the end of the working surface. The oscillator frequency is approximately $5 \mathrm{kHz}$. 
At the Environmental Magnetism Laboratory, Taras Shevchenko National University of Kyiv, we used the KLY (Agico, Chezh Republic) and MS2 (Bartington) to measure and then calculate mass-specific magnetic susceptibility $(X)$ and its frequency dependence $\left(X_{f d}\right)$ (185 samples of both soil and dust). The samples were analysed under natural condi- tions (without being dried immediately after sampling). Each sample was prepared and measured as recommended for the KLY and MS2, and mass-specific $\mathrm{X}$ was then calculated. Ten samples were analyzed at the Geophysical Center of Dourbes, the Royal Meteorological Institute of Belgium. We used an MPMS3 (Quantum Design magnetometer) to measure hysteresis, the frequency dependence of MS, and remanent magnetization. The MPMS3 provides accurate measurement results in a temperature range of $1.8-400 \mathrm{~K}\left(-271.35\right.$ to $\left.+126.85^{\circ} \mathrm{C}\right)$, field range $\pm 7 \mathrm{~T}$, frequency range $0.1 \mathrm{~Hz}-1$ $\mathrm{kHz}$. In addition, we used a Rotating Mag- netometer (Coercivity Meter) to obtain the isothermal magnetization curves (hysteresis, backfield, remanence acqui- sition) and the KLY-4-to measure the hightemperature dependence of MS. All of the hysteresis data obtained with the MPMS3 were also corrected for biasing remanences of the superconducting magnet resulting from flux trapping, prior to high-field slope correction.

The third stage of the measurements was performed at the Geosciences Montpellier Laboratory, a shared research facility administered by the CNRS, University of Montpel- lier and the University of the French Antilles in France (10 samples, the same number as that analysed at the Dourbes Center). A cryogenic magnetometer 2G-760R (www.2gent erprises.com), equipped with a degausser system controller 2G-600 and an anhysteretic remanent magnetizer 2G-615, was used to acquire and measure the anhysteretic remnant magnetization (ARM). Low-field susceptibility versus tem- perature curves (KT curves) wa performed at low and high temperatures with a CS-L cryostat apparatus and a CS-3 furnace under Argon atmosphere coupled to the KLY-3 Kap- pabridge instrument (Agico, Czech Republic, https://www. agico.com).

\section{Results}

The values of mass-specific $X$ of the topsoil in the study areas of Truskavets are distributed over a wide range-from $8 \times 10^{-8} \mathrm{~m}^{3} / \mathrm{kg}$ to $162 \times 10^{-8} \mathrm{~m}^{3} / \mathrm{kg}$. The median and mean values for the measured magnetic parameters for each cat- egory of the samples are presented in Table 1.

The MS of the reference natural phaeozems and gley- sols is $\mathrm{X}=8-10 \times 10^{-8} \mathrm{~m}^{3} / \mathrm{kg}$. The soils sampled along the first transect near the railway had $x=29-162 \times 10^{-8} \mathrm{~m}^{3} / \mathrm{kg}$. The MS values obtained for the soils collected along the second transect, impacted by the road traffic, were: $x=36-155 \times 10^{-8} \mathrm{~m}^{3} / \mathrm{kg}$. To understand the spatial distribu- tion of MS, we performed a spatial analysis (blue square in Fig. 1) at the most highly urbanized point near the Stebnyk Ring. The results are presented in Fig. 2. The maximum values of MS ( $X=95-155 \times 10^{-8} \mathrm{~m}^{3} / \mathrm{kg}$ ) were detected for the soil samples from within $0-8 \mathrm{~m}$ from the road. With increas- ing distance from the road, closer to the forest, MS decreases

and at a distance of $20 \mathrm{~m}$ from the road $x=35-45 \times 10^{-8} \mathrm{~m}^{3} / \mathrm{kg}$. These values are still high compared to the natural ref- erence soils but the trend is obvious. Unfortunately, we were not able to measure the frequency 
dependence of MS for non-polluted soils due to the small values of their low- field MS. For the polluted soils, however, we registered: $x_{f d}=2-3 \%$, a value that confirms the presence of pollutants.

Data on the dust samples collected from the trees bark (sponges) supported the evidence obtained from our studies of the soil samples. The highest values of the volume MS (k) were detected for the trees located at the hot spots of both the road traffic and railway: $\mathrm{k}=18-48 \times 10^{-6} \mathrm{SI}$. Moreover, we registered slightly higher values for the samples taken near the railway compared to those from the transect running along the circular road (see Table 1).

To analyze the sources of magnetic signal in polluted soils, we measured the temperature dependence of the low- field MS at high and low temperatures. The results of two heating and cooling cycles for the magnetic susceptibility of polluted samples are presented in Fig. 3a-b. The shape of the curve representing the first heating cycle (Fig. 3a) indicates the magnetite-like phase domination with a Curie temperature near $580^{\circ} \mathrm{C}$. A peak at $500^{\circ} \mathrm{C}$ suggests neo- formation of magnetite that may have resulted from trace sulphide oxidation. The presence of trace amounts of sul- phides is evidenced by a minor peak in the heating curve near $300{ }^{\circ} \mathrm{C}$. Heating caused most of the magnetic mate- rial to transform into magnetite. This is confirmed by the second heating-cooling cycle (Fig. 3b) that indicates the dominance of a magnetite-like phase. The low-temperature measurement of MS (Fig. 3c) confirmed the Verwey transi- tion of magnetite near - 150 ${ }^{\circ} \mathrm{C}(123.15 \mathrm{~K})$, which is well visualized in our case.

Results of our study into magnetization dependence at low temperatures and high magnetic fields are summarized in Fig. 4. The rock magnetic analyses were carried out with the MPMS3. Figure 4a presents an example of measuring remanent magnetization acquired in a field of $7 \mathrm{~T}$ (IRM7T) at room temperature during zero-field cooling (ZFC) and warming (ZFW). To reduce the magnetic viscosity effect associated with grains possibly present in the samples, they were cooled down one hour after magnetization. The IRM $7 \mathrm{~T}$ was then measured continuously at a cooling/heating rate of $5 \mathrm{~K} / \mathrm{min}$ (1800 points per curve).

Both ZFC and ZFW curves progress rather smoothly, making the distinction of magnetic phase transitions such as the Verwey or Morin transition difficult. Therefore, the 1st derivative of the difference ZFC- ZFW curve was calculated. Due to the enhancement of noise in the measured data, a 90 point moving average filter was applied (Fig. 4b).

As is evident from Fig. 4a, cooling and warming curves split at around $90 \mathrm{~K}$ and the remanence after lowtemper-ature cycling is lower than that initially acquired. Despite the multiple peaks seen in Fig. 4a, b global maximum can be identified at $127 \mathrm{~K}$, close to the Verwey transition and the isotropic point of magnetite, i.e. 110-125 K and $130 \mathrm{~K}$, respectively (Özdemir and Dunlop 1999).

The results of measuring hysteresis parameters and study- ing remanence acquisition are given in Fig. 5. The hyster- esis measurements shown were made at 30 and at $300 \mathrm{~K}$. The measured data were corrected for biasing remanences of the superconducting magnet (red curves in Fig. 5) prior to applying a high-field slope correction. For the latter cor- rection, the saturation method (Bertotti 1998; Fabian 2006) was implemented. Before high-field slope correction, the data show a linear increase between 1 and $7 \mathrm{~T}$ at room tem- perature, while at low temperature an asymptotic behaviour is observed. The high-field behaviour at room and at low temperatures indicates the presence of paramagnetic miner- als. A zoom into the low-field 
region reveals the occurrence of ferrimagnetic minerals with low coercivity, $\mathrm{H}_{C}$ and $\mathrm{H}_{\mathrm{C}}$ ranging typically around 10 and $30-40 \mathrm{mT}$, respectively, and $\mathrm{M}_{\mathrm{rS}} / \mathrm{M}_{\mathrm{S}}$ being around 0.1 .

\section{Discussion}

As regards a semi-urban environment, magnetic anoma- lies of soils are mostly associated with the traffic volume, which is considered to be a major factor determining the degree of particle emissions derived from vehicle traffic (Bućko et al. 2010). Using magnetic measurements and analysing the infrastructure of Truskavets, we identified two main sources of soil and air pollution-road traffic and the railway. Magnetic data can be used as preliminary information about soil and air pollution when geochemical data is not available. The background for such an assump- tion is considered in Petrovský et al. (2013). Particulate matter containing heavy metals that have a detrimental effect on the environment has been known to accumulate in the soil and on the trees bark near road and railway lines. Figure 6 presents the Day plot parameters for the polluted soil from Truskavets. Our results are in agreement with those obtained by Bućko et al. (2010), who concluded that the magnetic parameters of hysteresis, isothermal rema- nence magnetization acquisition curves and thermomag- netic data indicate coarse-grained (pseudo-singledomain/ multi-domain) magnetite as the primary magnetic phase. Moreover, there have been reports on a positive correla- tion between magnetic susceptibility and other magnetic parameters (Morton-Bermea et al. 2009; Yang et al. 2012a, b), which is important for further investigation.

As has been mentioned above, the Curie temperature near $580{ }^{\circ} \mathrm{C}$ in the heating run shows that the predominant mag- netic phase should be magnetite-like phase. This suggestion was confirmed by the Verwey transition of magnetite near $-150^{\circ} \mathrm{C}$. However, it is more difficult to interpret a minor peak in the heating curve near $300^{\circ} \mathrm{C}$. Although there is a possibility of sulphides being present, it might also point to a small number of single domain (SD) magnetic particles (Yang et al. 2012a, b). Stable SD particles could account for a pedogenic (natural soil) contribution to the total magnetic signal in the soil.

The $S_{\text {ratio }}$ (Maxbauer et al. 2016) close to 1 for both the soil and dust samples suggests the predominance of low coercivity magnetite in the polluted samples, as opposed to the natural soils and dust from the sites that are not affected by road traffic or railway pollution. At the same time, the values $0.75,0.79$, and 0.80 provide evidence of the contribu- tion of pedogenic high-coercivity minerals to the polluted soil. The natural gleysols and phaeozems from the forest show a lower $S_{\text {ratio, }}$, which indicates the predominance of high coercivity minerals such as haematite and goethite (Robertson et al. 2003).

The natural soil of the study area is weakly magnetic (Menshov and Sukhorada 2012) compared to other types of soils that have been investigated in Ukraine (Menshov et al. 2018). Nevertheless, determining reference values is essential to improving the interpretation of data on soil pollution. Results obtained by Fialová et al. (2006) suggest that lithology has a major effect on soil magnetic proper- ties. However, in cases of anthropogenic impact, man-made sources of pollution should be discriminated from lithogenic and pedogenic magnetic phases. The frequency dependence of magnetic susceptibility Xfd data may be used to depict the relative concentration of the superparamagnetic (SP) grains (Dearing et al. 1996). Low Xfd 
values identified in the Truskavets topsoil near the main roadway and railway are indicative of predominant multidomain (MD) magnetic grain size assemblages with the $X_{\mathrm{fd}} \sim 2 \%$.

Thermomagnetic studies of magnetization show that sam- ples from the sites with the effect of combined road traffic and railway pollution consist mainly of MD magnetite, the steepest slopes occurring in the range of the Verwey transi- tion and IRM $7 \mathrm{~T}$ being lower after cycling through the iso- tropic point of magnetite. The latter phenomenon is related to the unpinning of loosely pinned domain walls (Özdemir and Dunlop 1999). The fact that no abrupt change in rema- nence is seen around the isotropic point may be explained by the oxidation degree, i.e. the samples containing maghae- mite. Evidence of other magnetic phases (e.g. haematite) is hindered by the noise in the data.

The hysteresis values (see Fig. 5) are in agreement with the low-temperature remanence measurement (see Fig. 4) indicating the presence of larger, i.e. pseudo-single domain (PSD) or multidomain grains.

\section{Conclusions}

We registered gleysols and phaeozems (both slightly mag- netic in the Carpathian Foredeep of Ukraine) as the pre- dominant natural non-polluted soils in Truskavets with the MS of up to $8-10 \times 10^{-8} \mathrm{~m}^{3} / \mathrm{kg}$, which is a very low value for the Ukraine soils. In contrast, the polluted soils collected from the sampling sites and under areal research near the roadway and railway showed a much higher MS: $\mathrm{X}=36-162 \times 10^{-8} \mathrm{~m}^{3} / \mathrm{kg}$. The presence of pollutants in the soil samples was confirmed by the frequency dependence of magnetic susceptibility with values of $x_{f d} \sim 2 \%$.

The magnetic mineralogical analyses such as thermomag- netic studies, hysteresis and remanence acquisition, and $\mathrm{S}_{\text {ratio }}$ identified the magnetite-like phase as the main magnetic mineral responsible for the magnetic enhancement found in the polluted soils. Non-polluted soils, however, may contain a small number of SD particles and high coercivity minerals such as haematite and goethite. The obtained results sup- port the evidence presented by other researchers and suggest that magnetic parameters should be taken into account when tracing air and soil pollution, which poses a serious threat to human health. Thus, we strongly believe that magnetic analysis is a highly effective method that could contribute to the routine pollution monitoring and assessment schemes.

\section{References}

Bertotti G (1998) Hysteresis in magnetism. Academic Press, San Diego Bourliva A, Papadoupoulou L, Aidona E (2016) Study of road dust magnetic phases as the main carrier of potentially harmful trace elements. Sci Total Environ 553:380-391. https://doi.org/10.1016/j.scitotenv.2016.02.149

Brevik EC, Pereg L, Steffan J, Burgess LC (2018) Soil ecosystem ser- vices and human health. Curr Opin Environ Sci Health 5:87-92. https://doi.org/10.1016/j.coesh.2018.07.003

Bućko MS, Magiera T, Pesonen LJ, Janus B (2010) Magnetic, geo- chemical, and microstructural characteristics of road dust on roadsides with different traffic volumes: case study from Finland. Water Air Soil Pollut 209(1-4):295-306. https://doi.org/10.1007/ s11270-009-0198-2

Cao L, Appel E, Hu S, Yin G, Lin H, Rösler W (2015) Magnetic response to air pollution recorded by soil and dust-loaded leaves in a changing industrial environment. Atmos Environ 119:304-313. https://doi.org/10.1016/j.atmosenv.2015.06.017 
Cho DW, Jeon BH, Chon CM, Schwartz FW, Jeong Y, Song H (2015) Magnetic chitosan composite for adsorption of cationic and anionic dyes in aqueous solution. J Ind Eng Chem 28:60-66. https:// doi.org/10.1016/j.jiec.2015.01.023

Dankoub Z, Ayoubi S, Khademi H, Sheng-Gao LU (2012) Spatial distribution of magnetic properties and selected heavy metals in calcareous soils as affected by land use in the Isfahan region. Central Iran Pedosphere 22(1):33-47

Day R, Fuller M, Schmidt VA (1977) Hysteresis properties of titano- magnetites: grain-size and compositional dependence. Phys Earth Planet Inter 13:260-267. https://doi.org/10.1016/0031- 9201(77)90108-X

Dearing JA, Hay KL, Baban SMJ, Huddleston AS, Wellington EMH, Loveland P (1996) Magnetic susceptibility of soil: an evaluation of conflicting theories using a national data set. Geophys J Int 127(3):728-734. https://doi.org/10.1111/j.1365-246X.1996.tb040 51.x

Fabian K (2006) Approach to saturation analysis of hysteresis meas- urements in rock magnetism and evidence for stress dominated magnetic anisotropy in young mid-ocean ridge basalt. Phys Earth Planet Inter 154:299-307. https://doi.org/10.1016/j. pepi.2005.06.016

Felipe-Sotelo M, Andrade JM, Carlosena A, Tauler R (2007) Temporal characterisation of river waters in urban and semi-urban areas using physico-chemical parameters and chemometric methods. Anal Chim Acta 583(1):128-137

Fialová H, Maier G, Petrovský E, Kapička A, Boyko T, Scholger R, Team MAGPROX (2006) Magnetic properties of soils from sites with different geological and environmental settings. J Appl Geophys 59(4):273-283. https://doi.org/10.1016/j.jappg eo.2005.10.006

Frančišković-Bilinski S, Bilinski H, Maldini K, Milović S, Zhang Q, Appel E (2017) Chemical and magnetic tracing of coal slag pollutants in karstic river sediments. Environ Earth Sci 76:476. https ://doi.org/10.1007/s12665-017-6792-5

Gadirov VG, Eppelbaum LV, Kuderavets RS, Menshov OI, Gadirov KV (2018) Indicative features of local magnetic anomalies from hydrocarbon deposits: examples from Azerbaijan and Ukraine. Acta Geophys 66(6):1463-1483. https://doi.org/10.1007/s1160 0-0180224-0

Gargiulo JD, Chaparro MA (2016) Particulate matter pollution from a small coke-burning factory: soil magnetic screening and its relation with a simple atmospheric dispersion model. Stud Geophys Geod 60(2):316-331. https://doi.org/10.1007/s11200-015-1244-8

Jordanova D, Jordanova N, Petrov P (2014) Magnetic susceptibility of road deposited sediments at a national scale-Relation to population size and urban pollution. Environ Pollut 189:239-251. https ://doi.org/10.1016/..envpol.2014.02.030

Kapička A, Petrovský E, Ustjak S, Macháčková K (1999) Proxy map- ping of fly-ash pollution of soils around a coal-burning power plant: a case study in the Czech Republic. J Geochem Explor 66(1):291-297. https://doi.org/10.1016/S0375-6742(99)00008-4

Liu D, Ma J, Sun Y, Li Y (2016) Spatial distribution of soil mag- netic susceptibility and correlation with heavy metal pollu- tion in Kaifeng City, China. CATENA 139:53-60. https://doi. org/10.1016/j.catena.2015.11.004

Lourenço AM, Sequeira E, Sant'Ovaia H, Gomes CR (2014) Magnetic, geochemical and pedological characterisation of soil profiles from different environments and geological backgrounds near Coimbra, Portugal. Geoderma 213:408-418. https://doi.org/10.1016/j.geode rma.2013.07.035

Lu S, Yu X, Chen Y (2016) Magnetic properties, microstructure and mineralogical phases of technogenic magnetic properties (TMP's) in urban soils: Their source identification and eenviron- mental implications. Sci Total Environ 543:239-247. https://doi. org/10.1016/j.scitotenv.2015.11.046

Magiera T, Parzentny H, Rog L, Chybiorz R, Wawer M (2015) Spatial variation of soil magnetic susceptibility in relation to different emission sources in southern Poland. Geoderma 255-256:94-103. https://doi.org/10.1016/j.geoderma.2015.04.028

Maher BA, Moore C, Matzka J (2008) Spatial variation in vehicle- derived metal pollution identified by magnetic and elemental analysis of roadside tree leaves. Atmos Environ 42(2):364-373. https://doi.org/10.1016/j.atmosenv.2007.09.013

Matzka J, Maher BA (1999) Magnetic biomonitoring of roadside tree leaves: identification of spatial and temporal variations in vehiclederived particulates. Atmos Environ 33:4565-4569

Maxbauer DP, Feinberg JM, Fox DL (2016) Magnetic mineral assem- blages in soils and paleosols as the basis for paleoprecipitation proxies: a review of magnetic methods and challenges. Earth Sci Rev 155:28-48

Mitchell R, Maher BA, Kinnersley R (2010) Rates of particulate pol- lution deposition onto leaf surfaces: temporal and inter-species magnetic analyses. Environ Pollut 158:1472-1478. https://doi. org/10.1016/j.envpol.2009.12.029

Menshov O, Sukhorada A (2012) Soil magnetism in Ukraine. Sci Bull Natl Mining Univ 127(1):15-22 
Menshov O, Kuderavets R, Chobotok I (2014) Magnetic field and mag- netic susceptibility investigation at the hydrocarbon extraction areas in Carpathian Foredeep. EAGE Geoinformatics 2014-13th International Conference on Geoinformatics-Theoretical and Applied Aspects pp 61-65.

Menshov O, Kuderavets R, Vyzhva S, Maksymchuk V, Chobotok I, Pastushenko T (2016) Magnetic studies at Starunia paleontological and hydrocarbon bearing site (Carpathians, Ukraine). Stud Geophys Geod 60(4):731-746. https://doi.org/10.1007/s1120 0-0160621-2

Menshov O, Kruglov O, Vyzhva S, Nazarok P, Pereira P, Pastush- enko T (2018) Magnetic methods in tracing soil erosion, Kharkov Region Ukraine. Stud Geophys Geod 62(4):681-696. https://doi. org/10.1007/s11200-018-0803-1

Morton-Bermea O, Hernandez E, Martinez-Pichardo E, Soler-Are- chalde AM, Santa-Cruz RL, Gonzalez-Hernandez G, UrrutiaFucugauchi J (2009) Mexico City topsoils: Heavy metals vs. magnetic susceptibility. Geoderma 151(3):121-125. https://doi. org/10.1016/j.geoderma.2009.03.019

Norouzi S, Khademi H, Faz Cano A, Acosta JA (2016) Biomagnetic monitoring of heavy metals contamination in deposit atmospheric dust, a case study from Isfahan. Iran J Environ Manag 173:55-64. https://doi.org/10.1016/j.jenvman.2016.02.035

Özdemir Ö, Dunlop DJ (1999) Low-temperature properties of a sin- gle crystal of magnetite oriented along principal magnetic axes. Earth Planet Sci Lett 165:229-239. https://doi.org/10.1016/S0012 -821X(98)00269-6

Pereira P, Bogunovic I, Munoz-Rojas M, Brevik EC (2018) Soil eco- system services, sustainability, valuation and management. Curr Opin Environ Sci Health 5:7-13. https://doi.org/10.1016/j.coesh .2017.12.003

Petrovský E, Zbořil R, Grygar TM, Kotlík B, Novák J, Kapička A, Grison H (2013) Magnetic particles in atmospheric particulate matter collected at sites with different level of air pollution. Stud Geophys Geod 57(4):755-770. https://doi.org/10.1007/s1120 0-013-0814-

Robertson DJ, Taylor KG, Hoon SR (2003) Geochemical and min- eral magnetic characterisation of urban sediment particulates, Manchester UK. Appl Geochem 18(2):269-282. https://doi. org/10.1016/S0883-2927(02)00125-7

Slaczka A, Kruglov S, Golonka J, Oszczypko N, Popadyuk I (2006) Geology and hydrocarbon resources of the Outer Carpathians, Poland, Slovakia and Ukraine: General geology. In: Golonka J and Picha FJ (Eds) The Carpathians and their foreland Geology and hydrocarbon resources. American Association of Petroleum Geologists Memoir 84: 221-258. Doi: 10.1306/985610M843070

Szuszkiewicz M, Łukasik A, Magiera T, Mendakiewicz M (2016) Combination of geo-pedo-and technogenic magnetic and geochemical signals in soil profiles-Diversification and its interpre- tation: a new approach. Environ Pollut 214:464-477. https://doi. org/10.1016/j.envpol.2016.04.044

Taghipour M, Ayoubi S, Khademi H (2011) Contribution of litho- logic and anthropogenic factors to surface soil heavy metals in western Iran using multivariate geostatistical analyses. Soil Sedi- ment Contam Int J 20(8):921-937. https://doi.org/10.1080/15320 383.2011.620045

Yang T, Liu Q, Zeng Q, Chan L (2012a) Relationship between mag- netic properties and heavy metals of urban soils with different soil types and environmental settings: implications for magnetic map- ping. Environ Earth Sci 66(2):409-420. https://doi.org/10.1007/ s12665-011-1248-9

Yang P, Yang M, Shao H (2012b) Magnetic susceptibility and heavy metals distribution from risk-cultivated soil around the iron-steel plant, China. Clean: Soil, Air, Water 40(6):615-618. https://doi. org/10.1002/clen.201100269

Yang P, Byrne JM, Li H, Shao HB (2016) Evaluation of semi-arid arable soil heavy metal pollution by magnetic susceptibility in the Linfen basin of China. Arid Land Res Manag 30(3):258-268

Yurtseven-Sandker A, Cioppa MT (2016) Tracking the historical traces of soil pollution from an iron-sintering plant by using magnetic susceptibility in Wawa, Ontario, Canada. Water Air Soil Pollut 227(12):434. https://doi.org/10.1007/s11270-016-3140-4

WRB (2015) World reference base for soil resources 2014. Interna- tional soil classification system for naming soils and creating legends for soil maps. FAO, Rome. 
Figure 1 :
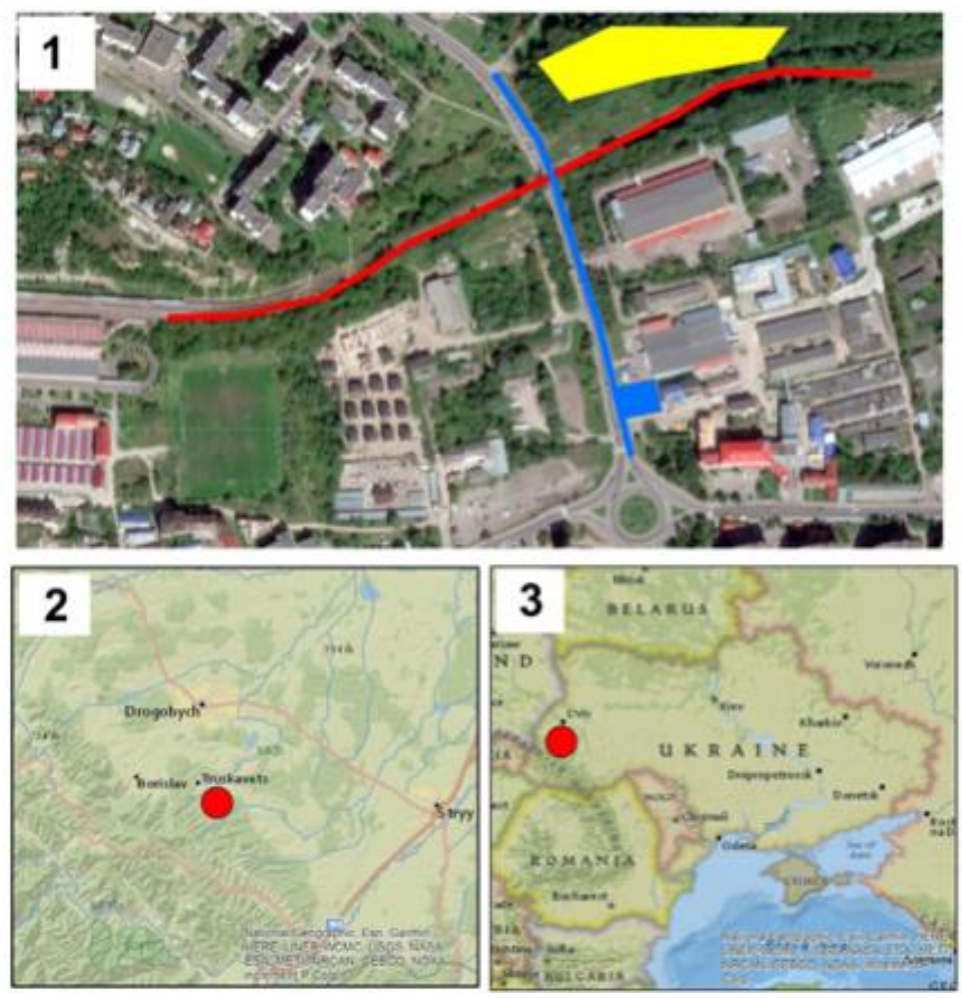

Fig. 1 Site overview: 1 -study area in Truskavets, red line-Transect 1 along railway, blue line-Transect 2 along roadway, blue square — area of spatial MS investigation, yellow area — study site in forest; 2 - Truskavets district in Lviv region, red point—study site; 3- Truskavets district in Ukraine, red point—study site 


\section{Figure 2 :}

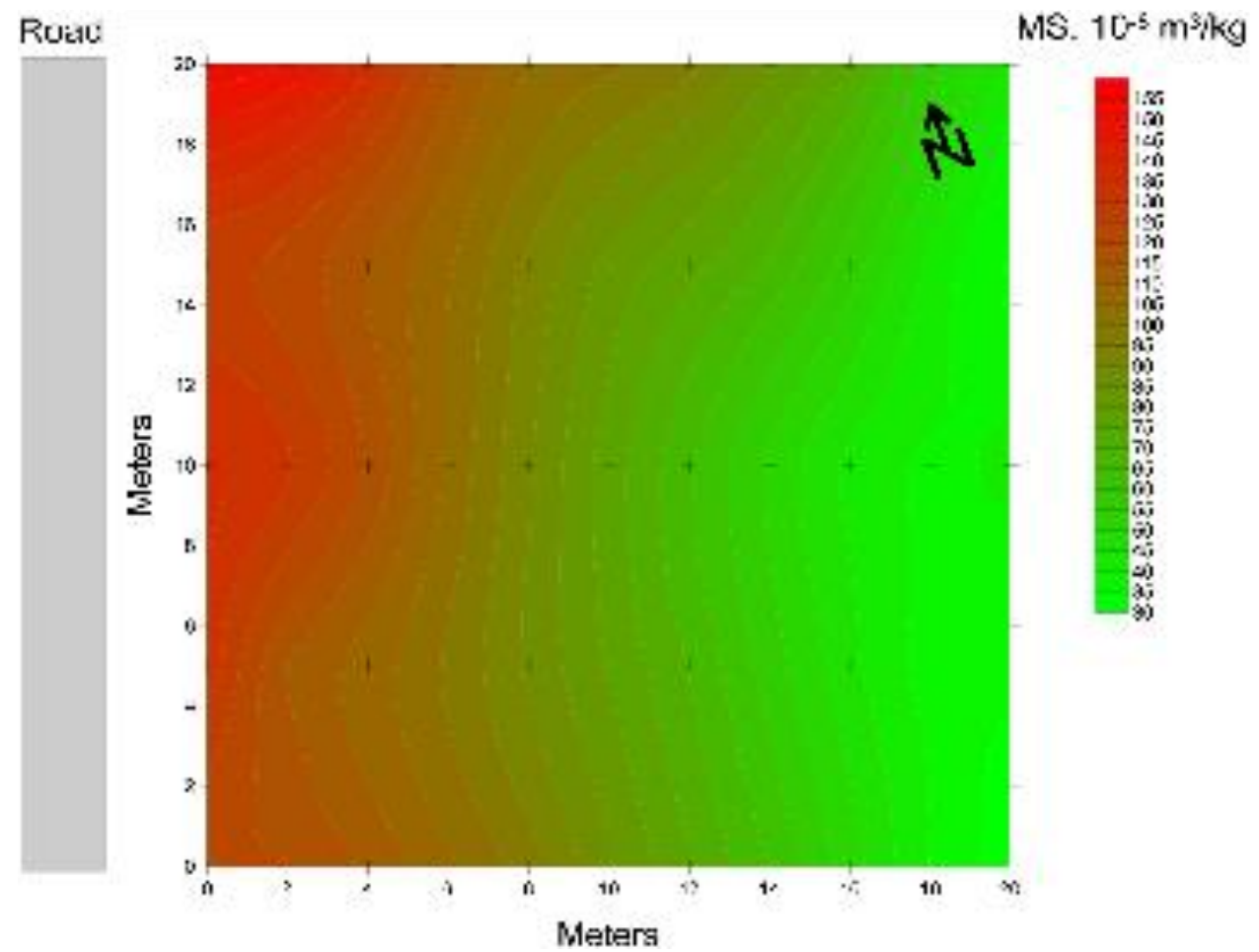

Fig. 2 Spatial distribution of mass specific magnetic sus- ceptibility of polluted roadside topsoil in the semi-urban area of Truskavets (blue square in the southern part of study area in Fig. 1) 


\section{Figure 3 :}
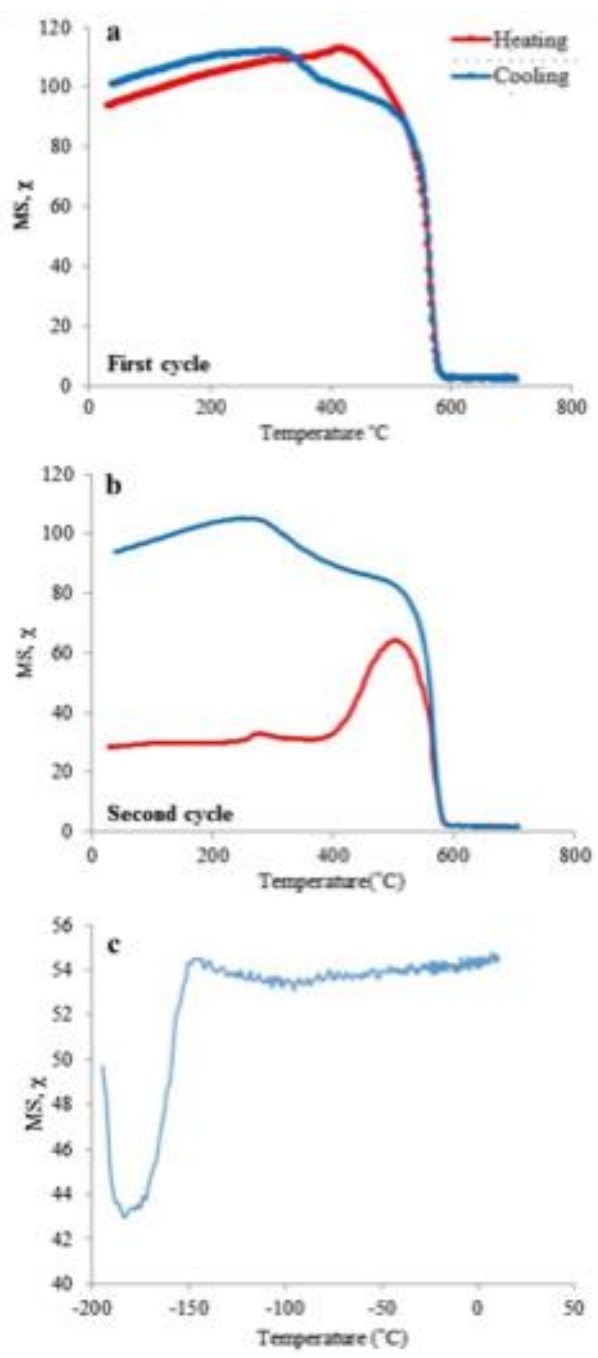

Fig. 3 Temperature dependence of magnetic susceptibility of the Tp-2b sample of soil affected by both road traffic and railway pollution: a the first heating-cooling cycle, b the second heating-cooling cycle. Red lines_heating curves, blue lines—cooling curves. c low- temperature measurement 


\section{Figure 4 :}
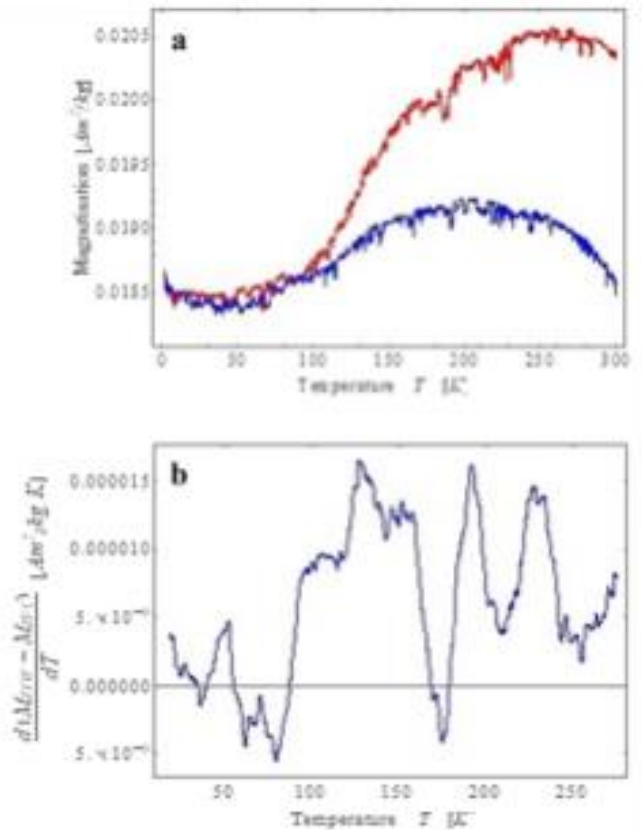

Fig.4 Low-temperature dependence of magnetization of the Tp-2b sample of soil affected by both road traffic and railway pollution: a red line — heating curves (ZFW), blue line (ZFC) — cooling curves; $b$ the 1st derivative of the difference ZFC- ZFW 


\section{Figure 5 :}
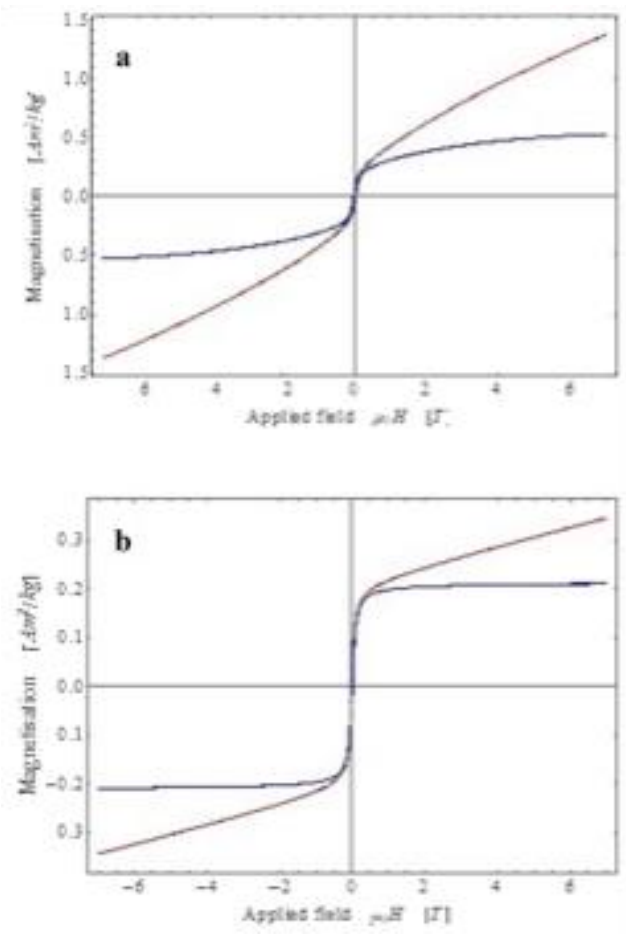

Fig. 5 Hysteresis loops of the Tp-2b sample of soil affected by both road traffic and railway pollution: a hysteresis at $30 \mathrm{~K}$; b hysteresis at $300 \mathrm{~K}$. Red and blue curves refer to raw data and the high-field slope corrected data, respectively 


\section{Figure 6 :}

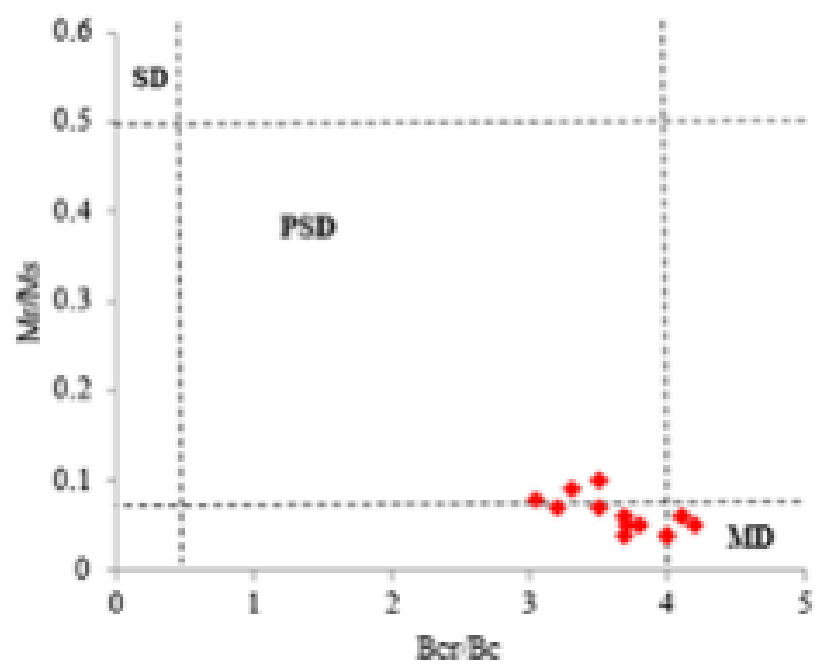

Fig. 6 Day plot (Day et al. 1977) for the samples of polluted soil from Truskavets: SD single-domain particles, PSD pseudo- singledomain particles, MD multidomain particles

\begin{tabular}{|c|c|c|c|c|c|c|c|c|c|c|}
\hline \multirow[t]{2}{*}{ Sample } & \multirow[t]{2}{*}{$N$} & \multirow{2}{*}{$\begin{array}{l}\text { Mass-specific } \\
\chi \times 10^{-8} \mathrm{~m}^{3} / \mathrm{kg} \\
\text { Median }\end{array}$} & \multirow{2}{*}{$\begin{array}{l}\text { Volume } \kappa \times 10^{-6} \\
\text { Median }\end{array}$} & \multirow{2}{*}{$\begin{array}{l}\chi_{\mathrm{fd}} \% \\
\text { Median }\end{array}$} & \multirow[t]{2}{*}{$N$} & \multirow{2}{*}{$\begin{array}{l}S_{\text {ratio }} \\
\text { Mean }\end{array}$} & \multirow{2}{*}{$\begin{array}{l}\mathrm{Bc}, \mathrm{mT} \\
\text { Mean }\end{array}$} & \multirow{2}{*}{$\begin{array}{l}\text { Bcr, mT } \\
\text { Mean }\end{array}$} & \multirow{2}{*}{$\begin{array}{l}\mathrm{Mr}, \mathrm{mAm}^{2} / \mathrm{kg} \\
\text { Mean }\end{array}$} & \multirow{2}{*}{$\begin{array}{l}\mathrm{Ms}, \mathrm{mAm} / \mathrm{kg} \\
\text { Mean }\end{array}$} \\
\hline & & & & & & & & & & \\
\hline Reference topsoil (forest site) & 20 & 9 & 15 & - & 2 & 0.71 & 11.5 & 40 & 0.701 & 6.497 \\
\hline Polluted roadside and railway soil (transect $1-$ red line) & 60 & 150 & 173 & 2 & 2 & 0.75 & 8 & 29.5 & 7.504 & 116.902 \\
\hline Polluted roadside soil (transect 2-blue line) & 40 & 105 & 121 & 2 & 2 & 0.99 & 9 & 29 & 10.362 & 135.288 \\
\hline Grid survey (blue square) & 55 & 82 & 97 & 3 & - & - & - & - & - & - \\
\hline Reference dust (forest site) & 2 & - & 6 & - & 2 & 0.69 & 12.5 & 38 & 0.831 & 8.871 \\
\hline Roadside dust (transect 1 -red line) & 4 & - & 18 & - & 4 & 0.79 & 8 & 33.5 & 1.635 & 26.810 \\
\hline Roadside and railway dust (transect 2-blue line) & 4 & - & 27 & - & 4 & 0.80 & 8 & 33 & 2.502 & 37.227 \\
\hline
\end{tabular}

